\title{
A Review on Recent Patents and Applications of Inorganic Material Binding Peptides
}

\author{
Veeranjaneyulu Thota and Carole C Perry*
}

\begin{abstract}
Biomolecular and Materials Interface Research Group, Interdisciplinary Biomedical Research Centre, Nottingham Trent University, Clifton Lane, Nottingham NG11 8NS, United Kingdom
\end{abstract}

\begin{abstract}
Over the past decade, significant progress has been made in the identification of novel material binding peptides having affinity to a wide range of target materials and their use in nanobiotechnological innovations. These material binding peptides (MBPs), also known as solid/ substance binding peptides (SBPs) can be isolated using combinatorial display technologies such as phage display (PD), surface display (cell, bacterial, yeast, mRNA) exhibit material specific selectivity and affinity towards a range of inorganic and organic nanomaterial surfaces including metals, metal oxides, minerals, semiconductors and biomolecules. MBPs serve as mediators in bringing nanotechnology and biotechnology under one umbrella by linking solid nanoparticles with biomolecules including proteins, bioactive peptide motifs, bifunctional binding peptides, enzymes, antigens and antibody fragments. As the utilization and application of these inorganic binding peptides as molecular connectors, molecular assemblers and material specific synthesizers in nanotechnology has been expanding rapidly, so too has growing commercial interest in patenting such innovations. In this review, we present the past, current and future developments and applications of inorganic MBPs specific to nanomaterials and their applications.
\end{abstract}

Keywords: Affinity, application, biomolecule, combinatorial peptide display, material binding peptide, mediator, nanotechnology, selectivity.

\section{INTRODUCTION}

MBPs have attracted considerable interest in the development of innovative nanostructured materials in particular because of their promising and growing applications in nanotechnology. These MBPs are also called inorganic binding peptides (IOBPs) or substrate binding peptides (SUBPs) or solid binding peptides (SBPs) or genetically engineered peptides for inorganics (GEPIs). MBPs are short amino acid peptide sequences that are genetically constructed and show specific affinity to a target material through combinatorial display approaches which include phage display [1-6], cell surface display [7-10], ribosome display [11-14] and mRNA display [15-18] technologies. Although nanomaterials have been designed and produced decades ago, their utilization in nano- or biotechnology is limited due to poor solubility and biocompatibility issues. However, several strategies have been developed to overcome the potential safety concerns and eventually, peptide display technologies came into existence by managing greater control over the nanomaterials without compromising their physical, chemical and functional properties.

G.P Smith, for the first time used phage display technology as a powerful tool to identify ligands for numerous targets in 1985 [1]. From there on, phage or cell surface displayed (7-15mers) libraries have become ubiquitous in selecting and screening peptides having strong

*Address correspondence to this author at the Interdisciplinary Biomedical Research Centre, Nottingham Trent University, Clifton Lane, NG11 8NS, Nottingham, UK; Tel: +44-115-8486695; E-mail: Carole.Perry@ntu.ac.uk affinity towards a range of inorganic material surfaces such as metals (Ag [19-21], Au [22, 23], Pt [24], Pd [25]), metal oxides $\left(\mathrm{SiO}_{2}\right.$ [26-30], $\mathrm{ZnO}[31,32], \mathrm{TiO}_{2}$ [33-35], $\mathrm{Fe}_{2} \mathrm{O}_{3}$ [36, 37], $\mathrm{IrO}_{2}$ [38], $\mathrm{Al}_{2} \mathrm{O}_{3}$ [24, 39], $\mathrm{Cu}_{2} \mathrm{O}$ [31]), minerals (calcite, hydroxyapatite, graphite, mica, sapphire) [40-42], semiconductors (CdS, GaN, GaAs and $\mathrm{ZnS}$ ) [43-45], carbon materials (graphene, carbon nanotubes) [46, 47] and polymer materials [48, 49]. These isolated peptides have many practical applications in biomineralization [32, 50, 51], synthesis and fabrication of inorganic nanomaterials [40, 5258], immobilization of nanoparticles onto inorganic or organic surfaces and surface functionalization [34, 38, 5961]. Now, it is starting to be possible to create novel materials using biological linkers to join more than one type of material generating hybrids with unique electronic, mechanical, magnetic or photonic properties [26, 27].

The aim of this paper is to summarize and discuss recent progress in patents on MBPs specifically exploring inorganic nano surfaces like metals, metal oxides, minerals, carbon based materials, polymer based materials, magnetic materials and semiconductors by peptide display strategies and their utilization in the generation of advanced nanomaterials.

In order to get a clear picture on the number of patents present to date relevant to MBPs and their applications, a thorough online search was conducted using the available free national and worldwide databases which include EPO Espacenet, WIPO patent scope, USPTO, Google patent search, Patent lens etc. along with commercial databases including Derwent and Patbase. The key words used to find all the relevant patents were combinatorial/ phage displayed 
peptides, material binding peptides, metal binding peptides (Gold $(\mathrm{Au})$, Silver (Ag), Titanium (Ti), Platinum (Pt), Palladium (Pd), Cobalt, Copper, Nickel, Lead, Cadmium and Aluminum), metal oxide binding peptides (Iron oxide $\left(\mathrm{Fe}_{2} \mathrm{O}_{3}\right)$, Lanthanide oxide, Silica or silicon dioxide $\left(\mathrm{SiO}_{2}\right)$, Quartz, Zeolites, Zinc oxide ( $\mathrm{ZnO})$, Palladium oxide (PdO), Cobalt oxide $(\mathrm{CoO})$, Manganese oxide $\left(\mathrm{MnO}_{2}\right)$, Calcium Oxide, Cuprous/ copper oxide $\left(\mathrm{Cu}_{2} \mathrm{O} / \mathrm{CuO}\right)$, Zirconium oxide $\left(\mathrm{ZrO}_{2}\right)$, Tin Oxide $\left(\mathrm{SnO}_{2}\right)$, Chromium oxide and Aluminum oxide), mineral binding peptides (Clay, Calcium phosphate, Calcium carbonate and Hydroxyapatite), Carbon based binding peptides (Graphene, Carbon nanotubes,
Graphite, Fullerenes and Diamond), Semiconductor binding peptides (Zinc Sulfide, Gallium Arsenide, Cadmium Sulfide, Germanium and combinations), interfacial binding peptides and polymer binding peptides. Both English and American spellings were included in the searches. The initial number of patents found related to material or IOBPs were 981. After reading and excluding irrelevant patents such as organic binding peptides, works published before 2001, repeated patents, documents not in English etc., 51 highly relevant IOBPs patents published from 2001 onwards were selected and analyzed.

\section{COMBINATORIAL DISPLAY PROCESS ON NANOMATERIAL SURFACES}

The connection between inorganic materials and biomolecules is not new in nature and exists naturally through the process of biomineralization. Through this, complex inorganic nanostructures including metal oxides and minerals are synthesized by certain species like magnetite, an iron oxide (Mms Proteins) in bacteria [62-64], silica (silaffins) in diatoms [65-70], silica (silicatein) in sponges $[71,72]$ aragonite and calcite (chitin, proteins and polysaccharides) in mollusks [73]. Though artificial processes have been used to reproduce the biominerals or materials their quality is challenging. In order to meet the quality and demand, several research groups started their quest for better alternate routes to produce more efficient, reliable and bulk bionanomaterials using inspiration from nature. This lead to the discovery of novel biomimetic approaches where peptides having affinity towards any target inorganic material can be isolated and practically reproduced using combinatorial peptide libraries such as phage display [1-6], bacterial/ yeast display [7-10], ribosome, mRNA or cDNA display [11-18] and rational design [74-76] as shown in Figure 1.

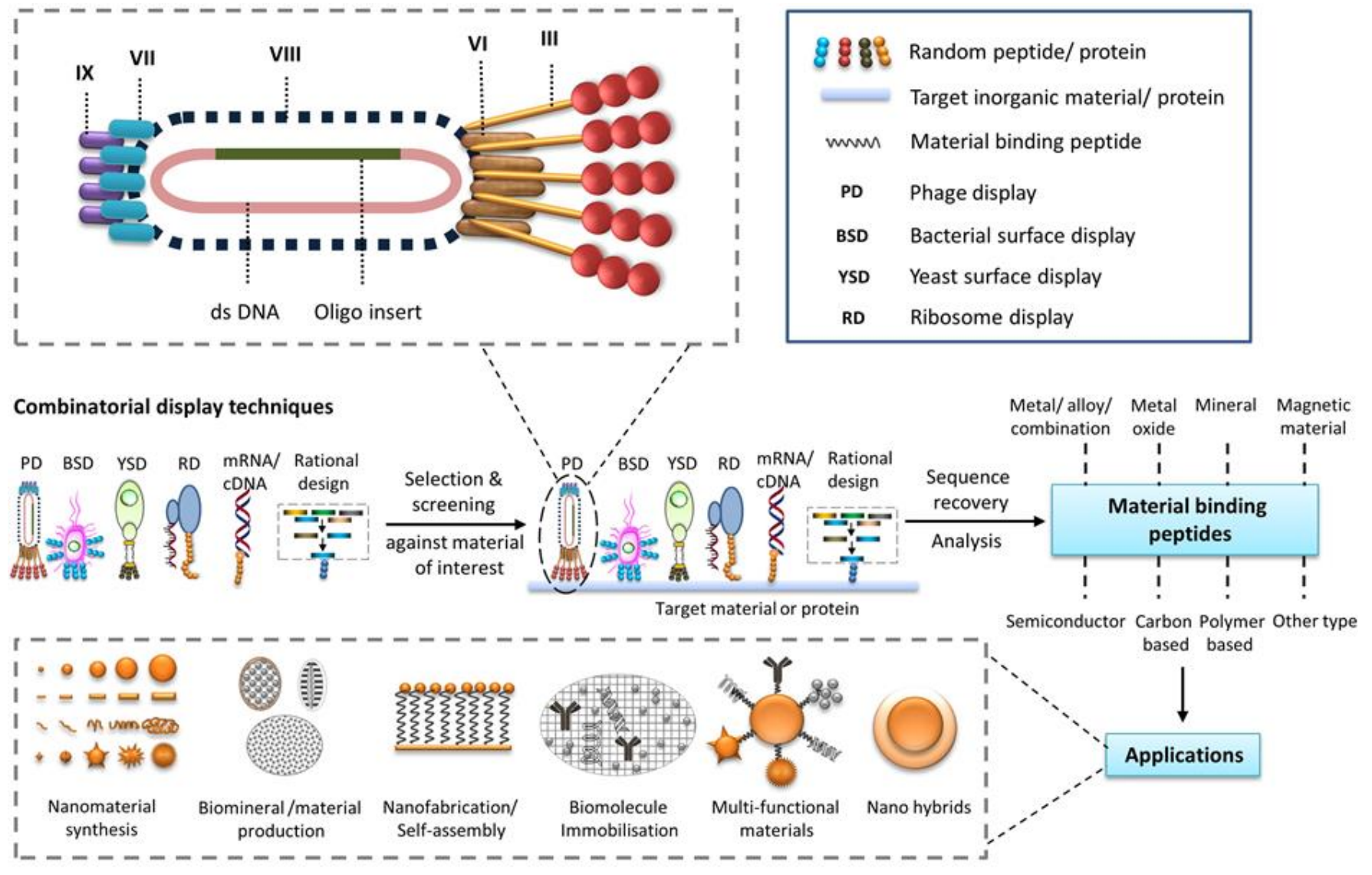

Figure 1: Schematic representation of different types of combinatorial display approaches used for selecting and screening of MBPs and their utilization towards practical applications including nanomaterial synthesis, assembly and fabrication of nanostructures, improving biocompatibility and biomolecule immobilization 
A combinatorial phage library consists of peptide, protein and antibody libraries many of which are commercially available. These libraries have been constructed by fusing DNA fragments into the genome of the phage or phagemid, and displaying the peptides on the surface of the phage coat proteins. For example, different types of phage coat proteins including pIII, pVI, pVII, pVIII and pIX have been used in phage libraries to display peptides, proteins and antibodies. as shown in Figure 1. The selection of coat proteins in the phage library depends on the type of display being looked for. For example, pIII phage capsid protein allows for monovalent display while pVIII allows for polyvalent display. A typical combinatorial display approach involves selection, screening and recovery of MBPs using any of the mentioned combinatorial technologies. So far, a range of biomimetic peptides showing specific affinity and molecular recognition for inorganic nanomaterials including metals, metal oxides, minerals, magnetic and semiconductor materials, carbon or polymer based materials have been isolated [19-49]. Further, these material specific peptides have been used for synthesizing simple to complex bio- or nano-materials, mediating the controlled biomineralzation process, directing self-assembly and nanofabrication of ordered structures, facilitating the immobilization of functional biomolecules and for constructing inorganicinorganic or organic-inorganic nano hybrids [50-61, 77-79].

\section{RECENT PATENTS ON INORGANIC MBPS AND THEIR APPLICATIONS}

This section summarizes relevant patents on inorganic MBPs and their application towards novel innovations as shown in Tables 1-6. In the patents (WO 078451 A2, US 7905943 B1, US 0172282 A1) Naik and coworkers [80, 81], used the phage display technique to screen and isolate MBPs specific to metals ( $\mathrm{Ag}, \mathrm{Au}, \mathrm{Co}, \mathrm{Pd}, \mathrm{Gd})$, metal oxides $\left(\mathrm{SiO}_{2}\right.$, $\mathrm{GeO}_{2}, \mathrm{Co}_{3} \mathrm{O}_{4}, \mathrm{Fe}_{2} \mathrm{O}_{3}, \mathrm{ZnO}, \mathrm{SnO}_{2}$ ) and other materials (ruby, carbon nanotubes). These peptides were further used as templates to mediate the controlled synthesis and formation of useful nanostructured materials alongside producing multifunctional bimetallic (gold-palladium) hybrid nanomaterials [81]. In addition to the existing combinatorial phage display approach for identifying novel peptides that are capable of showing high binding to inorganic surfaced nanomaterials, they developed a polymerase chain reaction (PCR)-driven phage display method to isolate peptide sequences specific to nanomaterials, thereby improving the process [82].

In a similar way, many patents have been registered obtaining SBPs having binding affinity towards a range of metals and metal oxides such as gold [83], silver, titanium and silicone [84], silica coated particles [85], titanium oxide and silicon containing compounds [86], titanium and stainless steel [87], iron oxide [88], dysprosium oxide [89] and ceramic materials [90] that utilize the same peptide sequences to initiate and synthesize nanostructures by tuning their size and shape [91]. Also, peptides designed through biomimetic and computational modelling have been used to precipitate stable and well defined titanium oxide nanoparticles of uniquely controlled morphologies including rectangular (KSSKK), spherical (SKSKKKSKSKKK, SKKKKKKKKKS, RRSSSRRSSSRR, RRRSRRRSRRRSRRR and SKKSKKK), flat and fused disks (SKKKKSSKKKKS, KKKSKSKKK, RRRSSRRRSSRRR, SKSKKKSKSKKKSKS and SSKKKSSKKK) and porous sheets (SKKKKKSKKKK, KKSSKKKKKKKKKS, KKKKSSKKKK, SKKSKKKKKKKK and SKKKSKKKK) without the use of high temperatures and pressures [92]. Additionally, these peptides revealed aggregate formation among themselves and the role of secondary structure in controlling morphology [92].

\section{Table 1. Relevant patents on metal, metal oxide, metal compound or combination binding peptides}

\begin{tabular}{|c|c|c|c|c|c|c|}
\hline No & $\begin{array}{l}\text { Patent number/ } \\
\text { Publication or } \\
\text { Renewal Years }\end{array}$ & Patent Title & Inventor/ Assignee/ Applicant & $\begin{array}{l}\text { Combinatorial } \\
\text { Library Used }\end{array}$ & $\begin{array}{l}\text { Target Inorganic } \\
\text { Material of Interest }\end{array}$ & $\begin{array}{l}\text { Refer } \\
\text { ence }\end{array}$ \\
\hline 1 & $\begin{array}{l}\text { WO } 078451 \text { A2 } \\
\text { US } 0035223 \text { A1 } \\
(2003,2006)\end{array}$ & $\begin{array}{l}\text { Method of isolating binding peptides } \\
\text { from a combinatorial phage display } \\
\text { library and peptides produced thereby }\end{array}$ & $\begin{array}{l}\text { Rajesh Naik, Morley Stone, } \\
\text { Daniel Carter/ New Century } \\
\text { Pharmaceuticals, Inc. (US) }\end{array}$ & $\begin{array}{l}\text { Phage display } \\
\text { (PhD. -12) }\end{array}$ & $\begin{array}{l}\text { Silver, silica, } \\
\text { germanium, cobalt and } \\
\text { iron oxides }\end{array}$ & 80 \\
\hline 2 & $\begin{array}{l}\text { US } 7905943 \text { B1 } \\
(2011)\end{array}$ & $\begin{array}{l}\text { Synthesis of hybrid inorganic } \\
\text { nanoparticle structures using peptides }\end{array}$ & $\begin{array}{l}\text { Joseph M. Slocik, Rajesh R. } \\
\text { Naik/ The United States of } \\
\text { America as Represented by The } \\
\text { Secretary of the Air Force (US) }\end{array}$ & Phage display & Palladium, gold & 81 \\
\hline 3 & $\begin{array}{l}\text { US } 0172282 \text { A1 } \\
\text { US } 0176760 \text { A1 } \\
(2006,2008)\end{array}$ & $\begin{array}{l}\text { Peptide templates for nanoparticle } \\
\text { synthesis obtained through PCR-driven } \\
\text { phage display method }\end{array}$ & $\begin{array}{l}\text { Rajesh Naik, Morley Stone, } \\
\text { Daniel Carter }\end{array}$ & $\begin{array}{l}\text { Phage display } \\
(\text { PhD. }-12)\end{array}$ & $\begin{array}{l}\text { Metals (Ag, } \mathrm{Au}, \mathrm{Co}, \\
\mathrm{Pd}, \mathrm{Gd}), \text { metal oxides } \\
\left(\mathrm{SiO}_{2}, \mathrm{GeO}_{2}, \mathrm{Co}_{3} \mathrm{O}_{4},\right. \\
\left.\mathrm{Fe}_{2} \mathrm{O}_{3}, \mathrm{ZnO} \mathrm{SnO}_{2}\right) \\
\text { other materials (Ruby, }\end{array}$ & 82 \\
\hline
\end{tabular}




\begin{tabular}{|c|c|c|c|c|c|c|}
\hline & & & & & carbon nanotubes) & \\
\hline 4 & $\begin{array}{l}\text { US } 0280220 \text { A1 } \\
\text { US } 8088740 \text { B2 } \\
(2010,2012)\end{array}$ & $\begin{array}{l}\text { Gold binding peptides and shape-and } \\
\text { size-tunable synthesis of gold } \\
\text { nanostructures }\end{array}$ & $\begin{array}{l}\text { Hor Gil Hur, Jung Ok Kim, Dae } \\
\text { Hee Kim, No Sang Myung/ } \\
\text { Gwangju Institute of Science } \\
\text { and Technology, Gwangju (KR) }\end{array}$ & $\begin{array}{l}\text { Phage display } \\
\text { (PhD. -12) }\end{array}$ & Gold & 83 \\
\hline 5 & $\begin{array}{l}\text { WO } 010031 \text { A1 } \\
\text { US } 7498403 \text { B2 } \\
(2005,2009)\end{array}$ & $\begin{array}{l}\text { Peptides capable of binding to titanium } \\
\text { silver silicone }\end{array}$ & $\begin{array}{l}\text { Kiyotaka Shiba, Kenichi Sano/ } \\
\text { Japan science and technology } \\
\text { agency, Tokyo (JP) }\end{array}$ & $\begin{array}{l}\text { Phage display } \\
\text { (C7C, D12) }\end{array}$ & Silver, titanium, silicon & 84 \\
\hline 6 & $\begin{array}{l}\text { US } 0158822 \text { A1 } \\
\text { WO 080419 A1 } \\
\text { (2010) }\end{array}$ & $\begin{array}{l}\text { Peptides that bind to silica coated } \\
\text { particles }\end{array}$ & $\begin{array}{l}\text { Fahnestock et al./ E.I. du Pont } \\
\text { de Nemours and Company, } \\
\text { Wilmington, DE (US) }\end{array}$ & Phage display & Silica & 85 \\
\hline 7 & $\begin{array}{l}\text { WO } 111832 \text { A1 } \\
\text { US 0045917 A1 } \\
(2011,2013)\end{array}$ & $\begin{array}{l}\text { Method for selecting polypeptide } \\
\text { sequence, metal oxide or silicon } \\
\text { containing compound binding peptide } \\
\text { and use thereof }\end{array}$ & $\begin{array}{l}\text { Akira Wada, Yoshihiro Ito, } \\
\text { Takashi Kitajima / } \\
\text { Riken (JP) }\end{array}$ & Phage display & $\begin{array}{l}\text { Titanium oxide, silicon } \\
\text { containing compounds }\end{array}$ & 86 \\
\hline 8 & $\begin{array}{l}\text { US } 0185870 \text { A1 } \\
\text { WO 072542 A2 } \\
(2003,2005)\end{array}$ & Interfacial biomaterials & $\begin{array}{l}\text { Mark W. Grinstaff, Daniel J. } \\
\text { Kenan, Elisabeth B. Walsh, } \\
\text { Crystan Middleton/ } \\
\text { Duke University (US) }\end{array}$ & $\begin{array}{l}\text { Phage display } \\
(\mathrm{PhD} .-13,19 \\
\mathrm{X}_{6} \mathrm{PX}_{6}, \mathrm{X}_{6} \mathrm{YX}_{6} \\
\text { and } \mathrm{SCX} \\
\text { libraries })\end{array}$ & $\begin{array}{l}\text { Titanium, stainless } \\
\text { steel }\end{array}$ & 87 \\
\hline 9 & $\begin{array}{l}\text { US } 0158837 \text { A1 } \\
\text { WO 080418 A1 } \\
(2010)\end{array}$ & Iron oxide-binding peptides & $\begin{array}{l}\text { Stephen R. Fahnestock, Kristy } \\
\text { N. Kostichka, Anju } \\
\text { Parthasarathy, Hong Wang/ } \\
\text { E.I. Dupont De Nemours and } \\
\text { Company (US) }\end{array}$ & $\begin{array}{l}\text { Chemical/ } \\
\text { synthetic } \\
\text { approach }\end{array}$ & Iron oxide & 88 \\
\hline 10 & $\begin{array}{l}\text { WO } 111407 \text { A1 } \\
(2015)\end{array}$ & $\begin{array}{l}\text { Rare earth material-binding peptide } \\
\text { and use thereof }\end{array}$ & $\begin{array}{l}\text { Takaaki Hatanaka, Nobuhiro } \\
\text { Ishida/ Kabushiki Kaisha } \\
\text { Toyota Chuo Kenkyusho (JP) }\end{array}$ & $\begin{array}{l}\text { Phage display } \\
\text { (Random T7 } \\
\text { library) }\end{array}$ & Dysprosium oxide & 89 \\
\hline 11 & $\begin{array}{l}\text { WO 007723 A1 } \\
(2010)\end{array}$ & $\begin{array}{l}\text { Peptide capable of binding to ceramic } \\
\text { material }\end{array}$ & $\begin{array}{l}\text { Hideki Kawamura, Kiyotaka } \\
\text { Shiba, Kenji Kashiwagi/ Murata } \\
\text { Manufacturing Co., Ltd., } \\
\text { Japanese Foundation for Cancer } \\
\text { Research (JP) }\end{array}$ & $\begin{array}{l}\text { Phage display } \\
\text { (Ph.D. }-12 \& \\
\text { C7C) }\end{array}$ & $\begin{array}{l}\text { Ceramic and metal or } \\
\text { oxide or ions } \\
\text { combinations, barium } \\
\text { titanate, titanium oxide, } \\
\text { zirconium oxide }\end{array}$ & 90 \\
\hline 12 & $\begin{array}{l}\text { US 0100969 A1 } \\
(2009,2016)\end{array}$ & $\begin{array}{l}\text { Templates for controlling synthesis of } \\
\text { nanoparticles into discrete assemblies }\end{array}$ & $\begin{array}{l}\text { Nathanial L. Rosi, Chun-Long } \\
\text { Chen/ University of Pittsburgh - } \\
\text { - Of the Commonwealth System } \\
\text { of Higher Education (US) }\end{array}$ & $\begin{array}{l}\text { Phage display } \\
\text { (PhD. -12) }\end{array}$ & Gold & 91 \\
\hline 13 & $\begin{array}{l}\text { US } 8834831 \text { B2 } \\
(2014)\end{array}$ & $\begin{array}{l}\text { Controlling morphology of titanium } \\
\text { oxide using designed peptides }\end{array}$ & $\begin{array}{l}\text { E. Stote II Robert, Shaun F. } \\
\text { Filocamo/ The United States of } \\
\text { America as represented by the } \\
\text { secretary of the army (US) }\end{array}$ & $\begin{array}{l}\text { Combination of } \\
\text { biomimetic and } \\
\text { computational } \\
\text { models }\end{array}$ & Titanium oxide & 92 \\
\hline 14 & $\begin{array}{l}\text { WO } 000493 \text { A2 } \\
\text { US } 0035245 \text { A1 } \\
(2010,2013)\end{array}$ & $\begin{array}{l}\text { Inorganic-binding peptides and quality } \\
\text { control methods using them }\end{array}$ & $\begin{array}{l}\text { Christelle Vreuls, Cécile Van } \\
\text { De Weerdt, Catherine } \\
\text { Archembeau, André Renard, } \\
\text { Joseph Martial/ Arcelormittal } \\
\text { Liege Research, Universite De } \\
\text { Liege Interface Entreprises } \\
\text { Universite (BE) }\end{array}$ & $\begin{array}{l}\text { Phage display } \\
\text { (PhD. }-12 \& \\
\text { C7C) }\end{array}$ & $\begin{array}{l}\text { Stainless steel, titanium } \\
\text { dioxide, zinc oxide }\end{array}$ & 93 \\
\hline 15 & $\begin{array}{l}\text { WO } 055980 \text { A2 } \\
\text { US 0219504 A1 } \\
(2011,2012)\end{array}$ & $\begin{array}{l}\text { Composite of a protein comprising } \\
\text { zinc oxide-binding peptides and zinc } \\
\text { oxide nanoparticles, and use thereof }\end{array}$ & $\begin{array}{l}\text { Nam-Hyuk Cho, Taek-Chin } \\
\text { Cheong, Seung-yong Seong, Ji } \\
\text { Hyun Min, Jun Hua Wu, } \\
\text { Young-Keun Kim/ Snu R\&Db } \\
\text { Foundation, Korea University } \\
\text { Research and Business } \\
\text { Foundation (KO) }\end{array}$ & $\begin{array}{l}\text { Combination of } \\
\text { peptide library } \\
\text { and motif } \\
\text { modification }\end{array}$ & Zinc oxide & 94 \\
\hline 16 & $\begin{array}{l}\text { US } 0249682 \text { A1 } \\
\text { WO 094095 A2 } \\
(2005,2006)\end{array}$ & $\begin{array}{l}\text { Long lasting waterproof sunscreen } \\
\text { comprising metal oxide and peptide } \\
\text { conditioner }\end{array}$ & $\begin{array}{l}\text { Janine Buseman-Williams, } \\
\text { Xueying Huang, Hong Wang, } \\
\text { Gary Whiting/ E.I. Dupont De } \\
\text { Nemours and Company (US) }\end{array}$ & $\begin{array}{l}\text { Phage display } \\
\text { (Ph. D.-7\& 12) }\end{array}$ & $\begin{array}{l}\text { Titanium dioxide, zinc } \\
\text { oxide, cerium oxide, } \\
\text { iron oxide and } \\
\text { combinations }\end{array}$ & 95 \\
\hline
\end{tabular}




\begin{tabular}{|c|c|c|c|c|c|c|}
\hline 17 & $\begin{array}{l}\text { WO } 056511 \text { A2 } \\
\text { US } 7618816 \text { B2 } \\
(2007,2009)\end{array}$ & Metal-binding therapeutic peptides & $\begin{array}{l}\text { Desmond Mascarenhas/ } \\
\text { Ontherix, Inc. (US) }\end{array}$ & $\begin{array}{l}\text { Combination of } \\
\text { cell display, } \\
\text { mutations }\end{array}$ & $\begin{array}{l}\text { Metal based } \\
\text { compounds and } \\
\text { domains }\end{array}$ & 96 \\
\hline 18 & $\begin{array}{l}\text { US } 0165225 \text { A1 } \\
\text { US } 8916376 \text { B2 } \\
(2012,2014)\end{array}$ & Metal-binding peptides & $\begin{array}{l}\text { Victor G. Stepanov, Yamei Liu, } \\
\text { George E. Fox, George W. } \\
\text { Jackson, Roger J. McNichols, } \\
\text { Weniger/ Biotex, Inc. (US) }\end{array}$ & $\begin{array}{l}\text { Artificial library } \\
\text { created ( } 20 \text { mer) }\end{array}$ & $\begin{array}{l}\text { Metal ions, organic } \\
\text { molecules, viral } \\
\text { particles and biological } \\
\text { molecules }\end{array}$ & 97 \\
\hline 19 & $\begin{array}{l}\text { WO } 079053 \text { A2 } \\
\text { US } 8569226 \text { B2 } \\
(2009,2013)\end{array}$ & $\begin{array}{l}\text { High Affinity metal-oxide binding } \\
\text { peptides with reversible binding }\end{array}$ & $\begin{array}{l}\text { Eric Mark Krauland, Stephen } \\
\text { Kottmann, Roberto Juan } \\
\text { Barbero, Angela Belcher/ } \\
\text { Massachusetts Institute of } \\
\text { Technology, Cambridge, MA } \\
\text { (US) }\end{array}$ & $\begin{array}{l}\text { Yeast surface } \\
\text { display, rational } \\
\text { design } \\
\text { methodology, } \\
\text { and genetic } \\
\text { engineering }\end{array}$ & $\begin{array}{l}\text { Oxides (sapphire, } \\
\text { quartz, thermally } \\
\text { grown oxide on silicon, } \\
\text { amorphous borosilicate } \\
\text { glass) or plasma } \\
\text { activated surfaces }\end{array}$ & 98 \\
\hline
\end{tabular}

Vreuls et al. invented a method to identify imperfections or non-homogenous conditions on the surface of materials thereby isolating specific nanoparticles from a mixture by using stainless steel (MTWDPSLASPRS), titanium oxide (LNAAVPFTMAGS) and zinc oxide binding peptides (VRTRDDARTHRK) [93]. In a separate patent (US 0219504 A1), Cho and co-workers created a complex protein joining zinc oxide binding peptides and zinc oxide nanoparticles together which resulted in an active agent for delivering drugs in vivo by an intracellular mode and helping in cell or MRI imaging [94]. In another patent (US 0249682 A), Williams and co-workers disclosed a sunscreen formulation that is resistant to water and lasts for a long time using peptide derived oxides such as titanium dioxide, zinc oxide, iron oxide, cerium oxide and a combination of nanoparticles alongside liquid as a sunscreen agent [95].

Desmond Mascarenhas in his patent (WO 056511 A2) described a method for treating selective human inflammatory diseases by delivering the metallic binding domain polypeptide linker complex (QCRPSKGRKRGFCW) in conjunction with curcumin and lycopene that showed specific binding to live cells that were under cellular stress resulting in increased cellular uptake, providing diagnostic information and altering a wide range of disease and cellular processes [96]. Alternatively, functionalised biomolecules were produced in cells or organisms by incorporating materials such as metals, toxins and peptides into the genome of cells and such modified cells have been used for isolating targeted molecules within the cells [97]. Furthermore, Krauland et al. (WO 079053 A2) engineered two peptides (GKGKGKGKGKGK \&

\section{GKGKGKGKGKGKASGKGKGKGKGKGK) using a} combination of yeast surface display, biopanning approaches, rational design strategy and genetic engineering that exhibit high affinity to metal oxide surfaces (eg. sapphire, quartz etc.) and bind in a reversible manner to plasma activated surfaces (eg. polystyrene, polydimethylsiloxane, polyurethane etc. upon exposure to oxygen plasma) where either of the peptides can selectively be released by exposing the oxide or plasma activated surfaces to high salt conditions and/or changing the electric field. In addition, these peptides when integrated selectively with protein or cells, act as a binding agent towards targeted oxide surfaces, thereby helping in the construction of biosensors [98].

Imamura et al. disclosed an invention related to a magnetic-biosubstance complex structure formation, where the biosubstance was immobilized on the carrier present on the magnetic substance. As a result of this, structures containing a carrier can be used as a vehicle for carrying or delivering diagnostic agents, bacteria, cells and drugs, separation and purification of proteins, DNA or RNA, as a carrier for enzyme reaction and for the formation of complex structures could be developed. The structure in the present invention (WO 097416 A1) comprises a magnetic substance, a peptide fragment and/or a gene capable of linking to a magnetic substance, preferably ferrous oxide $\left(\mathrm{Fe}_{2} \mathrm{O}_{3}\right)$ binding peptides selected from phage display and a biosubstance containing nucleic acids, proteins, lipids, carbohydrates and combinations thereof, preferably a polyhydroxyalkanoatesynthesizing enzyme [99].

\section{Table 2. Relevant patents on magnetic and semiconductor binding peptides}

\begin{tabular}{|c|c|c|c|c|c|c|}
\hline No & $\begin{array}{l}\text { Patent number/ } \\
\text { Publication or } \\
\text { Renewal years }\end{array}$ & Patent title & Inventor/ Assignee/ Applicant & $\begin{array}{l}\text { Combinatorial } \\
\text { library used }\end{array}$ & $\begin{array}{l}\text { Target inorganic } \\
\text { material of interest }\end{array}$ & $\begin{array}{l}\text { Refer } \\
\text { ence }\end{array}$ \\
\hline 20 & $\begin{array}{l}\text { WO } 097416 \text { A1 } \\
\text { US } 0108123 \text { A1 } \\
(2004,2008)\end{array}$ & $\begin{array}{l}\text { Magnetic substance-biosubstance } \\
\text { complex structure, peptide fragment } \\
\text { capable of linking to magnetic } \\
\text { substance and gene therefor, and } \\
\text { process for structure }\end{array}$ & $\begin{array}{l}\text { Takeshi Imamura, Tetsuya } \\
\text { Yano, Tsuyoshi Nomoto, } \\
\text { Shinya Kozaki, Tsutomu } \\
\text { Honma, Akiko Tsuchitani/ } \\
\text { Canon Kabushiki Kaisha (JP) }\end{array}$ & $\begin{array}{l}\text { Phage display } \\
\text { (Ph.D. -12) }\end{array}$ & Iron oxide $\left(\mathrm{Fe}_{2} \mathrm{O}_{3}\right)$ & 99 \\
\hline 21 & $\begin{array}{l}\text { US } 0148380 \text { A1 } \\
\text { US } 8372949 \text { B2 } \\
(2003,2013)\end{array}$ & Molecular recognition of materials & Angela M. Belcher (US) & $\begin{array}{l}\text { Phage display } \\
\text { library (7-12 a.a } \\
\text { fused to p3 }\end{array}$ & $\begin{array}{l}\text { Semiconductor and } \\
\text { magnetic material } \\
\text { combinations (GaN, }\end{array}$ & 100 \\
\hline
\end{tabular}




\begin{tabular}{|c|c|c|c|c|c|c|}
\hline & & & & protein) & $\begin{array}{l}\mathrm{ZnS}, \mathrm{CdS}, \mathrm{Fe}_{3} \mathrm{O}_{4} \text {, } \\
\mathrm{Fe}_{2} \mathrm{O}_{3}, \mathrm{CdSe}, \mathrm{ZnSe} \text { and } \\
\left.\mathrm{CaCO}_{3}\right)\end{array}$ & \\
\hline 22 & $\begin{array}{l}\text { WO } 026590 \text { A2 } \\
\text { US } 0003629 \text { A9 } \\
(2003,2012)\end{array}$ & $\begin{array}{l}\text { Biological control of nanoparticle } \\
\text { nucleation, shape and crystal phase }\end{array}$ & $\begin{array}{l}\text { Angela Belcher, Richard } \\
\text { Smalley, Esther Ryan, Seung- } \\
\text { Wuk Lee/ Board of Regents, } \\
\text { The University of Texas System } \\
\text { (US) }\end{array}$ & $\begin{array}{l}\text { Phage display } \\
\text { (Ph.D. -12, C7C) }\end{array}$ & $\begin{array}{l}\text { Metal oxides }\left(\mathrm{Fe}_{3} \mathrm{O}_{4} \text {, }\right. \\
\left.\mathrm{Fe}_{2} \mathrm{O}_{3} \text { and } \mathrm{CaCO}_{3}\right) \\
\text { Semiconductors }(\mathrm{GaAs} \text {, } \\
\text { InP, } \mathrm{ZnS}, \mathrm{CdS}, \mathrm{CdSe} \text {, } \\
\text { and } \mathrm{ZnSe})\end{array}$ & 101 \\
\hline 23 & $\begin{array}{l}\text { WO 029431 A2 } \\
\text { US 0300605 A1 } \\
(2003,2011)\end{array}$ & $\begin{array}{l}\text { Nanoscaling ordering of hybrid } \\
\text { materials using genetically engineered } \\
\text { mesoscale virus }\end{array}$ & $\begin{array}{l}\text { Angela M. Belcher, Seung-Wuk } \\
\text { Lee/ Board of Regents, } \\
\text { University of Texas System } \\
\text { (US) }\end{array}$ & $\begin{array}{l}\text { Phage display } \\
\text { (PhD. }-7 \& 12)\end{array}$ & $\begin{array}{l}\text { Semiconductors }(\mathrm{GaN}, \\
\mathrm{CdS}, \mathrm{FeS} \text {, and } \mathrm{ZnS} \text {, } \\
\mathrm{CdSe}, \mathrm{ZnSe})\end{array}$ & 102 \\
\hline 24 & $\begin{array}{l}\text { WO } 033488 \text { A2 } \\
(2004)\end{array}$ & $\begin{array}{l}\text { Peptide mediated synthesis of metallic } \\
\text { and magnetic materials }\end{array}$ & $\begin{array}{l}\text { Angela M. Belcher, Brian Reiss, } \\
\text { Chuanbin Mao, Daniel Solis/ } \\
\text { Board of Regents, University of } \\
\text { Texas System (US) }\end{array}$ & $\begin{array}{l}\text { Phage display } \\
\text { (PhD. -12) }\end{array}$ & $\begin{array}{l}\text { Metal materials } \\
\text { including magnetic } \\
\text { materials (e.g., Co, } \\
\text { CoPt SmCo }, \text { or FePt) }\end{array}$ & 103 \\
\hline 25 & $\begin{array}{l}\text { WO } 037856 \text { A2 } \\
\text { US } 0264166 \text { A1 } \\
(2005,2012)\end{array}$ & $\begin{array}{l}\text { Multifunctional biomaterials as } \\
\text { scaffolds for electronic, optical, } \\
\text { magnetic, semiconducting, and } \\
\text { biotechnological applications }\end{array}$ & $\begin{array}{l}\text { Angela M. Belcher, Beau R. } \\
\text { Peelle, Ki Tae Nam/ MIT, } \\
\text { Board of Regents, The } \\
\text { University of Texas System } \\
\text { (US) }\end{array}$ & $\begin{array}{l}\text { Phage display } \\
\text { (M13 pf1, fd1, } \\
\text { TMV) }\end{array}$ & $\begin{array}{l}\text { Semiconductors ( } \mathrm{ZnS} \\
\text { and CdS) } \\
\text { Metals (Au) }\end{array}$ & 104 \\
\hline 26 & $\begin{array}{l}\text { WO } 036992 \text { A2 } \\
\text { EP } 1545202 \text { A2 } \\
(2004,2005)\end{array}$ & Fabricated biofilm storage device & $\begin{array}{l}\text { Angela M. Belcher, Seung-Wuk } \\
\text { Lee, Brent L. Iverson, Soo- } \\
\text { Kwan Lee/ Board of Regents, } \\
\text { University of Texas System } \\
\text { (US) }\end{array}$ & $\begin{array}{l}\text { Phage display } \\
\text { (PhD. -12) }\end{array}$ & $\begin{array}{l}\text { Semiconductors (GaAs, } \\
\text { and ZnS) indium tin } \\
\text { oxide (ITO), metal, } \\
\text { metal alloy, mineral, or } \\
\text { combinations of } \\
\text { streptavidin BPs }\end{array}$ & 105 \\
\hline 27 & $\begin{array}{l}\text { WO } 067683 \text { A2 } \\
\text { US } 8846190 \text { B2 } \\
(2005,2014)\end{array}$ & Inorganic nanowires & $\begin{array}{l}\text { Angela M. Belcher, Chuanbin } \\
\text { Mao, Daniel J. Solis/ Board of } \\
\text { Regents, The University of } \\
\text { Texas System (US) }\end{array}$ & $\begin{array}{l}\text { M13 } \\
\text { bacteriophage } \\
\text { display }\end{array}$ & $\begin{array}{l}\text { Semiconductor, } \\
\text { metallic, metal oxide } \\
\text { and magnetic or } \\
\text { mixtures }\end{array}$ & 106 \\
\hline
\end{tabular}

Table 3. Relevant patents on carbon based MBPs

\begin{tabular}{|c|c|c|c|c|c|c|}
\hline No & $\begin{array}{l}\text { Patent number/ } \\
\text { Publication or } \\
\text { Renewal years }\end{array}$ & Patent title & Inventor/ Assignee/ Applicant & $\begin{array}{l}\text { Combinatorial } \\
\text { library used }\end{array}$ & $\begin{array}{l}\text { Target inorganic } \\
\text { material of interest }\end{array}$ & $\begin{array}{l}\text { Refer } \\
\text { ence }\end{array}$ \\
\hline 28 & $\begin{array}{l}\text { US 0309126 A1 } \\
(2014)\end{array}$ & $\begin{array}{l}\text { Peptide binding to graphitic materials } \\
\text { and phage including same }\end{array}$ & $\begin{array}{l}\text { Hyunjung Yi, Ki Young Lee, Ki } \\
\text { Young Lee, Chaun Jang, } \\
\text { Joonyeon Chang and Joonyeon } \\
\text { Chang/ Korea Institute of } \\
\text { Science and } \\
\text { Technology, seoul (KR) }\end{array}$ & $\begin{array}{l}\text { M13 phage } \\
\text { display (p8 } \\
\text { peptide library) }\end{array}$ & $\begin{array}{l}\text { Graphite, graphene, } \\
\text { carbon nanotube, } \\
\text { fullerene }\end{array}$ & 107 \\
\hline 29 & $\begin{array}{l}\text { WO } 102020 \text { A2 } \\
\text { US 0028316 A1 } \\
(2003,2011)\end{array}$ & Carbon nanotube binding peptides & $\begin{array}{l}\text { Anand Jagota, Steven Raymond } \\
\text { Lustig, Siqun Wang, Hong } \\
\text { Wang/ E. I. Du Pont De } \\
\text { Nemours and Company (US) }\end{array}$ & $\begin{array}{l}\text { Phage, bacterial } \\
\text { and yeast display }\end{array}$ & Carbon nanotube & 108 \\
\hline 30 & $\begin{array}{l}\text { US } 0156688 \text { A1 } \\
\text { US } 9029168 \text { B2 } \\
(2012,2015)\end{array}$ & $\begin{array}{l}\text { Use and making of biosensors utilizing } \\
\text { antimicrobial peptides for highly } \\
\text { sensitive biological monitoring }\end{array}$ & $\begin{array}{l}\text { Michael C. McAlpine, Manu } \\
\text { Sebastian Mannoor/ The } \\
\text { Trustees of Princeton University } \\
\text { (US) }\end{array}$ & $\begin{array}{l}\text { Phage display } \\
\text { and chemical } \\
\text { modification }\end{array}$ & $\begin{array}{l}\text { Graphene, microbial } \\
\text { and bacterial cells }\end{array}$ & 109 \\
\hline
\end{tabular}

Angela M. Belcher's group obtained many patents describing the selection and screening of IOBPs or viruses using phage display libraries and genetic engineering methods for varied materials including magnetic and semiconductor nanomaterials, and their utilization towards a range of applications [US $0148380 \mathrm{~A} 1$, WO 026590 A2, WO
029431 A2, WO 033488 A2, WO 037856 A2, WO 036992 A2, WO 067683 A2]. As illustration, the examples include, a method for selecting peptides containing one or more sequences having specific affinity for one or more magnetic or semiconducting crystal materials like $\mathrm{GaN}, \mathrm{ZnS}, \mathrm{CdS}$, $\mathrm{Fe}_{3} \mathrm{O}_{4}, \mathrm{Fe}_{2} \mathrm{O}_{3}, \mathrm{CdSe}, \mathrm{ZnSe}$ and $\mathrm{CaCO}_{3}$ [100], controlled 
nanoparticle synthesis including the desired target nanoparticle size, shape, growth and crystal phase by using the same phage or virus displayed nanoparticle binding peptides [101] and directing the assembly and fabrication of magnetic or semiconducting nanoscale hybrid materials mediated by genetically engineered mesoscale virus or phage displayed peptides [102, 103]. Additionally, these peptide or virus equipped multifunctional biomaterials have been used as templates or scaffolds for magnetic, electronic, optical and semiconducting applications [104], as well as for designing biofilm storage devices and nanowires [105, 106]. All the patents from this group describe a range of phage displayed or virus modifications that show specific binding to nanomaterial structures, as well as forming novel hybrid structures in the presence of modified biomaterials for specific binding. For instance, the polypeptide and oligomeric amino acid sequences can be expressed anywhere on the surface of the virus particles or coat proteins including pIII, pVI, pVII, pVIII and pIX and in the genome of the virus itself or at more than one site for modification of specific binding units. i.e. the ends of the polypeptide or virus particle can be altered to show specific recognition to an initial target material, whereas the genome of the virus can be manipulated to show specific affinity towards a second target material. In this process, multiple sites on the virus nanoparticles can be modified and utilized as scaffolds or templates for designing nanowires and novel devices [100-106].

Carbon based MBPs include graphene, fullerene and single or multi-walled carbon nanotubes. In separate inventions, two separate patents (US 0309126 A1 and WO 102020 A2) were issued for selecting peptides that were found to have specific binding interaction for a variety of graphitic materials such as graphene, highly oriented pyrolytic graphite, graphite alone and fullerenes [107] and for carbon nanotubes [108]. Moreover, these graphitic or carbon nanotube binding peptides have been used for application towards designing sensing devices to detect microorganisms. For example, a method for preparing sensors has been disclosed (US 0156688 A1), in which the sensing device was built by immobilising the antimicrobial peptide motifs having definite binding affinity for targets including E.coli, gram +ve or -ve bacteria, viruses, pathogens, fungi and varied cancer cells which can be read out upon changes in the electrical conductivity of the system [109].

\section{Table 4. Relevant patents on mineral binding peptides}

\begin{tabular}{|c|c|c|c|c|c|c|}
\hline No & $\begin{array}{l}\text { Patent number/ } \\
\text { Publication or } \\
\text { Renewal years }\end{array}$ & Patent title & Inventor/ Assignee/ Applicant & $\begin{array}{l}\text { Combinatorial } \\
\text { library used }\end{array}$ & $\begin{array}{l}\text { Target inorganic } \\
\text { material of interest }\end{array}$ & $\begin{array}{l}\text { Refer } \\
\text { ence }\end{array}$ \\
\hline 32 & $\begin{array}{l}\text { US } 7754680 \text { B2 } \\
(2010)\end{array}$ & $\begin{array}{l}\text { Peptides for binding calcium } \\
\text { carbonates and methods of use }\end{array}$ & $\begin{array}{l}\text { Scott D. Cunningham, Steven } \\
\text { Dale Ittel, John P. O'Brien, } \\
\text { Pierre E. Rouviere / E.I. du Pont } \\
\text { de Nemours and Company, } \\
\text { Wilmington, DE (US) }\end{array}$ & $\begin{array}{l}\text { Phage display } \\
\text { (PhD. -7\& 12) } \\
\text { and mRNA } \\
\text { display (p27 } \\
\text { mer) }\end{array}$ & Calcium carbonates & 111 \\
\hline 34 & $\begin{array}{l}\text { WO } 166626 \text { A1 } \\
\text { US } 0152672 \text { A1 } \\
(2012,2016)\end{array}$ & $\begin{array}{l}\text { Reagents and methods for treating } \\
\text { dental disease }\end{array}$ & $\begin{array}{l}\text { Mehmet Sarikaya, Martha } \\
\text { Somerman, Candan Tamerler- } \\
\text { Behar, Hanson Fong, Hai } \\
\text { Zhang, Mustafa Gungormus/ } \\
\text { University of Washington (US) }\end{array}$ & $\begin{array}{l}\text { Phage display } \\
\text { (PhD. -12, C7C) }\end{array}$ & Hydroxyapatite & 113 \\
\hline 35 & $\begin{array}{l}\text { US } 0070200 \mathrm{~A} 1 \\
(2010)\end{array}$ & $\begin{array}{l}\text { Method and system for designing } \\
\text { polypeptides and polypeptide-like } \\
\text { polymers with specific chemical and } \\
\text { physical characteristics }\end{array}$ & $\begin{array}{l}\text { Mehmet Sarikaya, Candan } \\
\text { Tamerler-Behar, Ersin Emre } \\
\text { Oren, Vaikuntanath V. } \\
\text { Samudrala (US) }\end{array}$ & $\begin{array}{l}\text { Phage display } \\
\text { (Ph.D.-12), } \\
\text { bacterial cell } \\
\text { surface display } \\
\text { (FliTrx) }\end{array}$ & $\begin{array}{l}\text { Hydroxyapatite, quartz } \\
\text { and gold }\end{array}$ & 114 \\
\hline
\end{tabular}

Similarly, mineral based MBPs for clay, calcium phosphate or calcium carbonate, hydroxyapatite and other materials have been identified. A number of patents were granted for peptides having specific binding affinity for a variety of minerals including clay [110], calcium carbonate [111] and hydroxyapatite materials [112-114]. Additionally, 
these mineral recognising peptides have been utilized for regenerating or inhibiting the growth of bone under controlled biomineralization conditions [112] and for curing dental diseases [112]. For example, Bertozzi ed. filed a patent for the identification of hydroxyapatite binding peptides which are similar to the type I collagen sequence (Gly-Pro-Hyp)x, a crucial material of extracellular matrices of native bone; with these sequences then being used as a template for synthesizing implantable bone by attaching a biocompatible and biodegradable substrate in mammals [112]. In contrast, Sarikaya et.al. developed a method for curing dental diseases and initiated dental mineralisation by constructing a recombinant polypeptide complex comprising phage displayed amelogenin and heterologous polypeptide containing substances derived from collagen, dentin, statherin, osteocalcin, enamilin and/or inorganic polypeptides and their affinity tags and markers [113]. In another patent (US $0070200 \mathrm{~A} 1$ ), he described a method and system for developing polypeptides which were initially characterized based on their specific affinities, physical and chemical properties for target inorganic substances and then applied those characterizations computationally to generate a polypeptide-scoring function resulting in the identification of further polypeptide sequences for additional applications in areas such as electronics, nanomedicine and nanotechnology [114].

\section{Table 5. Relevant patents on polymer binding peptides}

\begin{tabular}{|c|c|c|c|c|c|c|}
\hline No & $\begin{array}{l}\text { Patent number/ } \\
\text { Publication or } \\
\text { Renewal years }\end{array}$ & Patent title & Inventor/ Assignee/ Applicant & $\begin{array}{l}\text { Combinatorial } \\
\text { library used }\end{array}$ & $\begin{array}{l}\text { Target inorganic } \\
\text { material of interest }\end{array}$ & $\begin{array}{l}\text { Refer } \\
\text { ence }\end{array}$ \\
\hline 36 & $\begin{array}{l}\text { US } 0185870 \text { A1 } \\
\text { WO 072542 A2 } \\
(2003)\end{array}$ & Interfacial biomaterials & $\begin{array}{l}\text { Mark W. Grinstaff, Daniel J. } \\
\text { Kenan, Elisabeth B. Walsh, } \\
\text { Crystan Middleton/ } \\
\text { Duke University (US) }\end{array}$ & $\begin{array}{l}\text { Phage display } \\
(\mathrm{PhD} .-13,19 \\
\mathrm{X}_{6} \mathrm{PX}_{6}, \mathrm{X}_{6} \mathrm{YX}_{6} \\
\text { and } \mathrm{SCX}_{16} \mathrm{~S} \\
\text { libraries) }\end{array}$ & $\begin{array}{l}\text { Polystyrene, } \\
\text { polyurethane, } \\
\text { polycarbonate, } \\
\text { polyglycolic acid. }\end{array}$ & 87 \\
\hline 37 & $\begin{array}{l}\text { WO } 035612 \text { A2 } \\
\text { US } 0113741 \text { A1 } \\
(2004,2010)\end{array}$ & $\begin{array}{l}\text { Composition, method and use of bi- } \\
\text { functional biomaterials }\end{array}$ & $\begin{array}{l}\text { Angela M. Belcher, Christine J. } \\
\text { Schmidt, Kiley P. H. Miller, } \\
\text { Archit Sanghvi/ Board of } \\
\text { Regents, The University of } \\
\text { Texas Systems (US) }\end{array}$ & $\begin{array}{l}\text { Phage display } \\
\text { (Ph.D. -12) }\end{array}$ & $\begin{array}{l}\text { Polypyrrole doped } \\
\text { with chlorine (PPyCl) } \\
\text { and poly lactic acid-co- } \\
\text { glycolic acid (PLGA)) }\end{array}$ & 115 \\
\hline 38 & $\begin{array}{l}\text { WO 033482 A2 } \\
\text { US 0084618 A1 } \\
(2004,2012)\end{array}$ & Phenolic binding peptides & $\begin{array}{l}\text { Christopher Murray, Pilar } \\
\text { Tijerina, Franciscus Van } \\
\text { Gastel/ Danisco US Inc., Palo } \\
\text { Alto, CA (US) }\end{array}$ & $\begin{array}{l}\text { Phage display } \\
(\mathrm{PhD}-7 \& 12 \\
\text { C7C) }\end{array}$ & Phenolic compounds & 116 \\
\hline 39 & $\begin{array}{l}\text { US } 0141628 \text { A1 } \\
\text { US } 7906617 \text { B2 } \\
(2007,2011)\end{array}$ & $\begin{array}{l}\text { Polyethylene binding peptides and } \\
\text { methods of use }\end{array}$ & $\begin{array}{l}\text { Scott Cunningham, David } \\
\text { Lowe, John O'Brien, Hong } \\
\text { Wang, Antoinette Wilkins/ E.I. } \\
\text { du Pont de Nemours and } \\
\text { Company, Wilmington, DE } \\
\text { (US) }\end{array}$ & $\begin{array}{l}\text { Phage display } \\
\text { (PhD-7\& 12) }\end{array}$ & Polyethylene & 117 \\
\hline 40 & $\begin{array}{l}\text { US } 0265431 \text { A1 } \\
\text { US } 7858581 \mathrm{~B} 2 \\
(2007,2010)\end{array}$ & $\begin{array}{l}\text { PMMA binding peptides and methods } \\
\text { of use }\end{array}$ & $\begin{array}{l}\text { Scott Cunningham, David } \\
\text { Lowe, John O'Brien, Hong } \\
\text { Wang, Antoinette Wilkins / } \\
\text { E.I. du Pont de Nemours and } \\
\text { Company, Wilmington, DE } \\
\text { (US) }\end{array}$ & $\begin{array}{l}\text { Phage display } \\
\text { (PhD-7\& 12) }\end{array}$ & $\begin{array}{l}\text { Polymethylmethacrylat } \\
\text { e }\end{array}$ & 118 \\
\hline 41 & $\begin{array}{l}\text { US } 0310495 \mathrm{~A} 1 \\
(2010)\end{array}$ & $\begin{array}{l}\text { Peptides having affinity for poly } \\
\text { (benzyl methacrylate-co-methacrylic } \\
\text { acid) potassium salt copolymers and } \\
\text { methods of use }\end{array}$ & $\begin{array}{l}\text { Eberhard Schneider, Gregor } \\
\text { Schurmann, Peter Wagner, } \\
\text { Hong Wang, Gordon Mark } \\
\text { Cohen/ E. I. Du Pont De } \\
\text { Nemours and Company (US) }\end{array}$ & $\begin{array}{l}\text { mRNA and } \\
\text { phage display }\end{array}$ & $\begin{array}{l}\text { Poly (benzyl } \\
\text { methacrylate -co- } \\
\text { methacrylic acid) } \\
\text { potassium salt } \\
\text { copolymers }\end{array}$ & 119 \\
\hline 42 & $\begin{array}{l}\text { WO } 018964 \text { A2 } \\
\text { US } 0178390 \text { A1 } \\
(2009,2013)\end{array}$ & $\begin{array}{l}\text { System comprising bacteriophages and } \\
\text { particles that contain active substances }\end{array}$ & $\begin{array}{l}\text { Stefanie Eiden, Axel Eble, } \\
\text { Martin Weiss, Daniel Gordon } \\
\text { Duff, Olaf Bork, Holger Egger, } \\
\text { Bastian Budde, Sascha Plug/ } \\
\text { Bayer Technology Services } \\
\text { Gmbh }\end{array}$ & $\begin{array}{l}\text { Phage display } \\
\text { (PhD. -12, gpIII, } \\
\text { gpVII) }\end{array}$ & $\begin{array}{l}\text { Polycarbonate and } \\
\text { polyurethane surfaces }\end{array}$ & 120 \\
\hline 43 & $\begin{array}{l}\text { WO } 065573 \text { A1 } \\
\text { US 0279894 A1 } \\
(2009,2010)\end{array}$ & $\begin{array}{l}\text { Bacteriophages and coating material } \\
\text { for surfaces }\end{array}$ & $\begin{array}{l}\text { Stefanie Eiden, Axel Eble, } \\
\text { Bastian Budde, Sascha Plug, } \\
\text { Peter Krüger/ Bayer } \\
\text { Technology Services Gmbh, }\end{array}$ & $\begin{array}{l}\text { Phage display } \\
\text { (PhD. -12, gpIII, } \\
\text { gpVIII) }\end{array}$ & Polyurethane surfaces & 121 \\
\hline
\end{tabular}




\begin{tabular}{|l|l|l|l|l|l|}
\hline & & Bayer Material science & & & \\
\hline
\end{tabular}

A variety of synthetic polymers were displayed that link biological and non-biological surfaces resulting in the identification of polymer binding peptides and their utilization in generating unique functional nanomaterial surfaces. Synthetic and copolymer surfaces include polystyrene, polyurethane, polymethylmethacrylate, polycarbonate, polyurethane, polyglycolic acid, phenolic compounds and combinations of other nanomaterials thereof. A few patents were registered for selecting peptides or proteins found to interact specifically with polymer surfaces including polystyrene, polyurethane, polycarbonate, polyglycolic acid and combinations with metal or oxide nanomaterials [87], polypyrrole doped with chlorine and poly lactic acid-co-glycolic acid [115], phenolic compounds [116], polyethylene [117], polymethylmethacrylate [118], poly (benzyl methacrylate-co-methacrylic acid) potassium salt copolymers [119] and polycarbonate and polyurethane surfaces [120, 121]. Moreover, these polymer binding peptides along with proteins of bacteriophages have been utilized for the prolonged release of drugs [120] and as an active coating material for developing corrosion resistant surfaces [121].

\section{Table 6. Relevant patents on other MBPs}

\begin{tabular}{|c|c|c|c|c|c|c|}
\hline No & $\begin{array}{l}\text { Patent number/ } \\
\text { Publication or } \\
\text { Renewal years }\end{array}$ & Patent title & Inventor/ Assignee/ Applicant & $\begin{array}{l}\text { Combinatorial } \\
\text { library used }\end{array}$ & $\begin{array}{l}\text { Target inorganic } \\
\text { material of interest }\end{array}$ & $\begin{array}{l}\text { Refer } \\
\text { ence }\end{array}$ \\
\hline 44 & $\begin{array}{l}\text { WO } 048399 \text { A2 } \\
\text { US } 0364584 \text { A1 } \\
(2004,2014)\end{array}$ & Skin or hair binding peptides & $\begin{array}{l}\text { Giselle G. Janssen, Christopher } \\
\text { J. Murray, Deborah S. } \\
\text { Winetzky/ Danisco Us Inc. }\end{array}$ & $\begin{array}{l}\text { Phage display } \\
\text { (Ph.D. } 7 \& 12 \text {, } \\
\text { C7C) }\end{array}$ & Hair and Skin & 122 \\
\hline 45 & $\begin{array}{l}\text { US } 0222609 \text { A1 } \\
\text { WO } 126641 \text { A1 } \\
(2006,2007)\end{array}$ & $\begin{array}{l}\text { Peptide-based body surface colouring } \\
\text { reagents }\end{array}$ & $\begin{array}{l}\text { John O'Brien, Hong Wang, } \\
\text { Ying Wu/ E. I. Du Pont De } \\
\text { Nemours and Company (US) }\end{array}$ & $\begin{array}{l}\text { Phage display } \\
\text { (Ph.D. -12) }\end{array}$ & $\begin{array}{l}\text { Hair, nail, teeth, gums, } \\
\text { skin, and tissues of the } \\
\text { oral cavity. }\end{array}$ & 123 \\
\hline 46 & $\begin{array}{l}\text { US } 0107614 \text { A1 } \\
\text { WO } 057463 \text { A2 } \\
(2005,2008)\end{array}$ & Peptide-based conditioners & $\begin{array}{l}\text { Stephen Fahnestock, John } \\
\text { O'Brien, Hong Wang/ E. I. Du } \\
\text { Pont De Nemours and } \\
\text { Company (US) }\end{array}$ & $\begin{array}{l}\text { Phage display } \\
\text { (Ph.D. } 7 \text { \& 12) }\end{array}$ & $\begin{array}{l}\text { Hair, nail, gums, oral } \\
\text { cavity tissues and skin }\end{array}$ & 124 \\
\hline 47 & $\begin{array}{l}\text { WO } 028503 \text { A1 } \\
\text { US } 7759460 \text { B2 } \\
(2006,2010)\end{array}$ & $\begin{array}{l}\text { Peptide-based body surface reagents } \\
\text { for personal care }\end{array}$ & $\begin{array}{l}\text { Xueying Huang, John P. } \\
\text { O'brien, Hong Wang, Ying } \\
\text { Wu/ E. I. Du Pont De Nemours } \\
\text { and Company (US) }\end{array}$ & $\begin{array}{l}\text { Phage display } \\
\text { (Ph.D. 7\& 12) }\end{array}$ & Hair, Nail and Skin & 125 \\
\hline 48 & $\begin{array}{l}\text { US } 0247590 \text { A1 } \\
\text { WO } 117709 \text { A2 } \\
(2010)\end{array}$ & $\begin{array}{l}\text { Peptide-based systems for delivery of } \\
\text { cosmetic agents }\end{array}$ & $\begin{array}{l}\text { Douglas Robert Anton, Susan } \\
\text { Daly, Robert J. Bianchini, } \\
\text { Hong Wang, Pierre E. } \\
\text { Rouviere, Scott D. } \\
\text { Cunningham, Stephen R. } \\
\text { Fahnestock, Tanja Maria } \\
\text { Gruber/ Johnson \& Johnson, E. } \\
\text { I. Du Pont De Nemours and } \\
\text { Company (US) }\end{array}$ & & $\begin{array}{l}\text { Human hair, skin and } \\
\text { nail. }\end{array}$ & 126 \\
\hline 49 & $\begin{array}{l}\text { WO } 015163 \text { A1 } \\
\text { US } 0183373 \text { A1 } \\
(2009,2011)\end{array}$ & $\begin{array}{l}\text { Recombinant peptide production using } \\
\text { a cross-linkable solubility tag }\end{array}$ & $\begin{array}{l}\text { Albert W. Alsop, Qiong Cheng, } \\
\text { Linda Jane Decarolis, Stephen } \\
\text { R. Fahnestock, Tanja Maria } \\
\text { Gruber, Pierre E. Rouviere/ } \\
\text { E. I. Du Pont De Nemours and } \\
\text { Company (US) }\end{array}$ & $\begin{array}{l}\text { Phage, ribosome } \\
\text { and mRNA } \\
\text { display }\end{array}$ & $\begin{array}{l}\text { Hair, skin, nail, teeth, } \\
\text { cellulose, polymer and } \\
\text { clay. }\end{array}$ & 127 \\
\hline 50 & $\begin{array}{l}\text { US } 0141629 \text { A1 } \\
\text { US } 7709601 \text { B2 } \\
(2007,2010)\end{array}$ & $\begin{array}{l}\text { Nylon binding peptides and methods } \\
\text { of use }\end{array}$ & $\begin{array}{l}\text { Scott Cunningham, David } \\
\text { Lowe, John O'Brien, Hong } \\
\text { Wang, Antoinette Wilkins/ } \\
\text { E.I.du Pont de Nemours and } \\
\text { Company, Wilmington, DE } \\
\text { (US) }\end{array}$ & $\begin{array}{l}\text { Phage display } \\
\text { (Ph.D. }-7 \& 12 \text { ) }\end{array}$ & $\begin{array}{l}\text { Nylon agents } \\
\text { (pharmaceuticals, } \\
\text { markers, colorants, } \\
\text { conditioners and } \\
\text { fragrances) }\end{array}$ & 128 \\
\hline 51 & $\begin{array}{l}\text { WO } 079479 \text { A2 } \\
\text { US 0231251 A9 } \\
(2001,2013)\end{array}$ & Methods for selective targeting & $\begin{array}{l}\text { Giselle G. Janssen, Christopher } \\
\text { J. Murray, Deborah S. } \\
\text { Winetzky David A. Estell, Pilar }\end{array}$ & $\begin{array}{l}\text { Phage display } \\
\text { (Ph.D. -7-12) }\end{array}$ & $\begin{array}{l}\text { Selected fabrics, stains, } \\
\text { soil, pigments, skin, } \\
\text { hair, cytokines and }\end{array}$ & 129 \\
\hline
\end{tabular}




\begin{tabular}{|l|l|l|l|l|l|}
\hline & & & $\begin{array}{l}\text { Tijerina, Yiyou Chen/ } \\
\text { Genencor International, Inc. }\end{array}$ & receptors \\
\hline 52 & $\begin{array}{l}\text { US 7332356 B2 } \\
\text { (2004) }\end{array}$ & Fluorescent dye binding peptides & $\begin{array}{l}\text { Garry Nolan, Michael Rozinov/ } \\
\text { The Board of Trustees For The } \\
\text { Leland Stanford Junior } \\
\text { University (US) }\end{array}$ & $\begin{array}{l}\text { Phage display } \\
\text { (Ph.D.-12) }\end{array}$ & $\begin{array}{l}\text { Fluorophore dyes } \\
\text { (Fluorescein, oregon } \\
\text { green 514, rhodamine } \\
\text { red and texas red) }\end{array}$ \\
\hline
\end{tabular}

In the same way, a separate class of MBPs were also reported where one or more compounds binds to different specific targets under the presence of anti-targets. In simple terms, a peptide that binds specifically to compound A has been identified using compound $\mathrm{B}$ as an anti-target and compound B binding peptides in the presence of anti-target compound A. The compounds include coloring, conditioning, cosmetic and personal care reagents that are directly involved in improving the properties of keratin, a key component in skin, hair, nails and teeth. Various patents have been published where peptides having higher affinity for human body surfaces such as skin, hair, nail, teeth, pigment, gum or oral cavity; nylon agent and fluorophore dyes were selected and identified using phage, ribosome and mRNA libraries [122-130]. Although peptide based products have useful applications, their long lasting behavior remains a challenge. In order to improve the durability for these products, two or more agent binding peptides have been used alongside linkers [123-127]. Further, these body surface binding proteins or peptides have been used in day to day applications such as hair or nail coloring reagents [123], conditioners for hair or skin [124], personal care products for skin, teeth and associated pigments [125], as cosmetic delivery agents [126], recombinant peptide production [127] and for developing markers, fragrances, pharmaceutical products, selective fabrics and fluorophore dyes [128-130].

\section{CONCLUSION}

Biomimetic MBPs have emerged as a new frontline in the design of novel nanomaterials with improved/ controlled physical and chemical properties without affecting the structural or functional activities of the nanomaterials themselves which can be realized from the above discussion of recent literature and patents. Although combinatorial display technologies are firstly for selecting and identifying biomolecules against almost any material of interest and further towards generating more efficient and reliable peptide based nanostructures, the accuracy of molecular recognition for inorganic materials as a target and then translating practical (in vitro, in vivo or ex vivo and in silico) applications into product specific commercial success is still challenging unlike the situation where organic molecules are the targets of interest.

\section{CURRENT \& FUTURE DIRECTIONS}

The unique binding ability/nature of peptide libraries to select and screen specific material of interest, particularly inorganic materials has created much interest and potential to reach a wider scientific community which may ultimately lead to the development of even more novel bio- or nanomaterials. However, these libraries still possess drawbacks. These include their ability to bind to non-specific undesired targets [131, 132], under representation of the desired sequences and their properties due to having bias towards peptide/ protein position, composition, and expression [133] or $\mathrm{pH}$ and interaction specific intrinsic bias [30], thus many target specific strong MBPs are not found during the phage display process. Additionally, another important factor to consider is the limited fundamental understanding of peptide-material interactions which is a major bottle neck for generating peptide based inorganic nanomaterials with improved biostability/ compatibility, solubility and functionality and increased physico-chemical properties. In advancing our understanding of peptide mineral interactions a clear understanding of the solution behavior of both the peptide and the mineral is needed before the interaction of the two can be understood. As examples, in our research we have shown that by careful study of the particular properties of the material itself, for example silica [29, 30, 134] and $\mathrm{ZnO}[57,135,136]$ we can show that the size of particles $[29,30,134]$ and charge/ functionality on particles [30, 137] have clear effects on the binding of small peptides to minerals as well as the route by which a material is formed $[57,135,136]$ by moderating peptide mineral interaction.

Further, although, online databases are easily available for specific organic MBPs such as antimicrobial and anticancer peptides, no specific databases have been designed for inorganic MBPs obtained from distinct classes of combinatorial display techniques. We propose that such databases, with all the experimental and computational information relating to the different classes of nanomaterials and libraries should be built. These databases will find solutions for bias problems and improve our understanding of biomolecule-inorganic material interactions which will lead in turn to the development of smart nanomaterials and slowly reduce the sole dependence on in vitro display technologies to take this approach forward as is presently the case.

\section{LIST OF ABBREVIATIONS}

MBPs $=$ Material binding peptides

SBPs $=$ Solid binding peptides

IOBPs $=$ Inorganic binding peptides

GEPIs $=$ Genetically engineered peptides for inorganics

$\mathrm{PD}=$ Phage display

$\mathrm{BSD}=$ Bacterial surface display

YSD = Yeast surface display

$\mathrm{RD}=$ Ribosome display

\section{CONFLICT OF INTEREST}


The authors confirm that this article content has no conflict of interest.

\section{ACKNOWLEDGEMENTS}

We are thankful to AFOSR (FA9550-13-1-0040) for financial support over many years of research in this area.

\section{REFERENCES}

[1] Smith GP. Filamentous fusion phage: novel expression vectors that display cloned antigens on the virion surface. Science 1985; 228(4705): 1315-17.

[2] Winter G, Griffiths AD, Hawkins RE, Hoogenboom HR. Making antibodies by phage display technology. Annu Rev Immunol 1994; 12: 433-55.

[3] Hoogenboom HR, de Bruïne AP, Hufton SE, Hoet RM, Arends J, Roovers RC. Antibody phage display technology and its applications. Immunotechnology 1998 6; 4(1): 1-20.

[4] Azzazy HME, Highsmith Jr WE. Phage display technology: clinical applications and recent innovations. Clin Biochem 2002; 35(6): 425-45.

[5] Petrenko VA. Evolution of phage display: from bioactive peptides to bioselective nanomaterials. Expert Opin Drug Discovery 2008; 5(8): 825-36.

[6] Ullman CG, Frigotto L, Cooley RN. In vitro methods for peptide display and their applications. Briefings in Functional Genomics 2011; 10(3): 125-34.

[7] Kieke MC, Shusta EV, Boder ET, Teyton L, Wittrup KD, Kranz DM. Selection of functional T cell receptor mutants from a yeast surface-display library. Proc Natl Acad Sci 1999; 96(10): 5651-56.

[8] Feldhaus MJ, Siegel RW. Yeast display of antibody fragments: a discovery and characterization platform. J Immunol Methods 2004; 290(1-2): 69-80.

[9] Kondo A, Ueda M. Yeast cell-surface display-applications of molecular display. Appl Microbiol Biotechnol 2004; 64(1): 28-40.

[10] Shusta EV, Pepper LR, Cho YK. A decade of yeast surface display technology: where are we now? Comb Chem High Throughput Screen 2008; 11(2): 127-34.

[11] Hanes J, Plückthun A. In vitro selection and evolution of functional proteins by using ribosome display. Proc Natl Acad Sci 1997; 94(10): 4937-42.

[12] Schaffitzel C, Hanes J, Jermutus L, Plückthun A. Ribosome display: an in vitro method for selection and evolution of antibodies from libraries. J Immunol Methods 1999; 231(1-2): 119-35.

[13] Yan X, Xu Z. Ribosome-display technology: applications for directed evolution of functional proteins. Drug Discov Today 2006; 11(19-20): 911-16.

[14] Zahnd C, Amstutz P, Pluckthun A. Ribosome display: selecting and evolving proteins in vitro that specifically bind to a target. Nat Meth 2007; 4(3): 269-79.

[15] Xu L, Aha P, Gu K, et al. Directed evolution of high-affinity antibody mimics using mRNA display. Chem Biol 2002;9(8): 93342.

[16] Takahashi TT, Austin RJ, Roberts RW. mRNA display: ligand discovery, interaction analysis and beyond. Trends Biochem Sci 2003; 28(3): 159-65.

[17] Lipovsek D, Plückthun A. In-vitro protein evolution by ribosome display and mRNA display. J Immunol Methods 2004; 290(1-2): 51-67.

[18] Fukuda I, Kojoh K, Tabata N, et al. In vitro evolution of singlechain antibodies using mRNA display. Nucleic Acids Res 2006; 34(19): 127.

[19] Naik RR, Stringer SJ, Agarwal G, Jones SE, Stone MO. Biomimetic synthesis and patterning of silver nanoparticles. Nat Mater 2002 Nov; 1(3): 169-72.

[20] Chan P, Phan T, Kao MC, Dolan C, Tok JB-. Generating short peptidic ligands for silver nanowires from phage display random libraries. Bioorg Med Chem Lett 2006; 16(20): 5261-64.

[21] Currie HA, Deschaume O, Naik RR, Perry CC, Kaplan DL. Genetically engineered chimeric silk-silver binding proteins. Adv Funct Mater 2011; 21(15): 2889-95.
[22] Brown S. Metal-recognition by repeating polypeptides. Nat Biotechnol 1997; 15(3): 269-72.

[23] Hnilova M, Oren EE, Seker UO, et al. Effect of molecular conformations on the adsorption behavior of gold-binding peptides. Langmuir 2008;24(21): 12440-5.

[24] Sarikaya M, Tamerler C, Jen AK-, Schulten K, Baneyx F. Molecular biomimetics: Nanotechnology through biology. Nat Mater 2003; 2(9): 577-85.

[25] Pacardo DB, Sethi M, Jones SE, Naik RR, Knecht MR. Biomimetic synthesis of Pd nanocatalysts for the stille coupling reaction. ACS Nano 2009; 3(5): 1288-96.

[26] Naik RR, Brott LL, Clarson SJ, Stone MO. Silica-precipitating peptides isolated from a combinatorial phage display peptide library. J Nanosci Nanotechnol 2002; 2(1): 95-100.

[27] Eteshola E, Brillson LJ, Lee SC. Selection and characteristics of peptides that bind thermally grown silicon dioxide films. Biomol Eng 2005; 22(5-6): 201-04.

[28] Chen H, Su X, Neoh K, Choe W. QCM-D Analysis of binding mechanism of phage particles displaying a constrained heptapeptide with specific affinity to $\mathrm{SiO}_{2}$ and $\mathrm{TiO}_{2}$. Anal Chem 2006; 78(14): 4872-9.

[29] Patwardhan SV, Emami FS, Berry RJ, et al. Chemistry of aqueous silica nanoparticle surfaces and the mechanism of selective peptide adsorption. J Am Chem Soc 2012;134(14): 6244-56.

[30] Puddu V, Perry CC. Peptide adsorption on silica nanoparticles: Evidence of hydrophobic interactions. ACS Nano 2012; 6(7): 6356-63.

[31] Thai CK, Dai H, Sastry MSR, Sarikaya M, Schwartz DT, Baneyx F. Identification and characterization of $\mathrm{Cu}_{2} \mathrm{O}$ and $\mathrm{ZnO}$ binding polypeptides by escherichia coli cell surface display: Toward an understanding of metal oxide binding. Biotechnol Bioeng 2004; 87(2): 129-37.

[32] Umetsu M, Mizuta M, Tsumoto K, et al. Bioassisted roomtemperature immobilization and mineralization of zinc oxide - the structural ordering of $\mathrm{ZnO}$ nanoparticles into a flower-type morphology. Adv Mater 2005;17(21): 2571-5.

[33] Patwardhan SV, Patwardhan G, Perry CC. Interactions of biomolecules with inorganic materials: principles, applications and future prospects. J Mater Chem 2007; 17(28): 2875-84.

[34] Khatayevich D, Gungormus M, Yazici H, et al. Biofunctionalization of materials for implants using engineered peptides. Acta Biomater 2010;6(12): 4634-41.

[35] Sultan AM, Westcott ZC, Hughes ZE, et al. Aqueous peptide- $\mathrm{TiO}_{2}$ interfaces: isoenergetic binding via either entropically or enthalpically driven mechanisms. ACS Appl Mater Interfaces 2016;8(28): 18620-30.

[36] Brown S. Engineered iron oxide-adhesion mutants of the escherichia coli phage $\lambda$ receptor. Proc Natl Acad Sci USA 1992; 89(18): 8651-5.

[37] Lower BH, Lins RD, Oestreicher Z, et al. In vitro evolution of a peptide with a hematite binding motif that may constitute a natural metal-oxide binding archetype. Environ Sci Technol 2008;42(10): 3821-7.

[38] Nam YS, Magyar AP, Lee D, et al. Biologically templated photocatalytic nanostructures for sustained light-driven water oxidation. Nat Nano 2010;5(5): 340-4.

[39] Zuo R, Örnek D, Wood TK. Aluminum- and mild steel-binding peptides from phage display. Appl Microbiol Biotechnol 2005; 68(4): 505-9.

[40] Naik RR, Jones SE, Murray CJ, McAuliffe JC, Vaia RA, Stone MO. Peptide templates for nanoparticle synthesis derived from polymerase chain reaction-driven phage display. Adv Funct Mater 2004; 14(1): 25-30.

[41] Roy MD, Stanley SK, Amis EJ, Becker ML. Identification of a highly specific hydroxyapatite-binding peptide using phage display. Adv Mater 2008; 20(10): 1830-6.

[42] Chung W, Kwon K, Song J, Lee S. Evolutionary screening of collagen-like peptides that nucleate hydroxyapatite crystals. Langmuir 2011; 27(12): 7620-8.

[43] Whaley SR, English DS, Hu EL, Barbara PF, Belcher AM. Selection of peptides with semiconductor binding specificity for directed nanocrystal assembly. Nature 2000; 405(6787): 665-8. 
[44] Lee S, Mao C, Flynn CE, Belcher AM. Ordering of quantum dots using genetically engineered viruses. Science 2002; 296(5569): 892-5.

[45] Flynn CE, Mao C, Hayhurst A, et al. Synthesis and organization of nanoscale II-VI semiconductor materials using evolved peptide specificity and viral capsid assembly. J Mater Chem 2003;13(10): 2414-21.

[46] Kase D, Kulp III JL, Yudasaka M, Evans JS, Iijima S, Shiba K. Affinity selection of peptide phage libraries against single-wall carbon nanohorns identifies a peptide aptamer with conformational variability. Langmuir 2004; 20(20): 8939-41.

[47] Pender MJ, Sowards LA, Hartgerink JD, Stone MO, Naik RR. Peptide-mediated formation of single-wall carbon nanotube composites. Nano Lett 2006; 6(1): 40-4.

[48] Serizawa T, Sawada T, Matsuno H. Highly specific affinities of short peptides against synthetic polymers. Langmuir 2007; 23(22): 11127-33.

[49] Matsuno H, Sekine J, Yajima H, Serizawa T. Biological selection of peptides for poly(l-lactide) substrates. Langmuir 2008; 24(13): 6399-403.

[50] Gungormus M, Fong H, Kim IW, Evans JS, Tamerler C, Sarikaya M. Regulation of in vitro calcium phosphate mineralization by combinatorially selected hydroxyapatite-binding peptides. Biomacromolecules 2008; 9(3): 966-73.

[51] Chiu D, Zhou W, Kitayaporn S, Schwartz DT, Murali-Krishna K, Kavanagh TJ, et al. Biomineralization and size control of stable calcium phosphate core-protein shell nanoparticles: Potential for vaccine applications. Bioconjugate Chem 2012;23(3): 610-17.

[52] Kim J, Rheem Y, Yoo B, et al. Peptide-mediated shape- and sizetunable synthesis of gold nanostructures. Acta Biomaterialia 2010;6(7): 2681-9.

[53] Nam KT, Kim DW, Yoo PJ, et al. Virus-enabled synthesis and assembly of nanowires for lithium ion battery electrodes. Science 2006;312(5775): 885-8.

[54] Sarikaya M, Tamerler C, Schwartz DT, Baneyx F. Materials assembly and formation using engineered polypeptides. Annual Review of Materials Research 2004; 34: 373-408.

[55] Li Y, Huang Y. Morphology-controlled synthesis of platinum nanocrystals with specific peptides. Adv Mater 2010; 22(17): 19215.

[56] Tomczak MM, Gupta MK, Drummy LF, Rozenzhak SM, Naik RR. Morphological control and assembly of zinc oxide using a biotemplate. Acta Biomaterialia 2009; 5(3): 876-82.

[57] Limo MJ, Ramasamy R, Perry CC. ZnO Binding Peptides: Smart versatile tools for controlled modification of $\mathrm{ZnO}$ growth mechanism and morphology. Chem Mater 2015; 27(6): 1950-60.

[58] Tamerler C, Kacar T, Sahin D, Fong H, Sarikaya M. Genetically engineered polypeptides for inorganics: A utility in biological materials science and engineering. Mater Sci Eng C 2007; 27(3): 558-64.

[59] Estephan E, Saab M, Larroque C, et al. Peptides for functionalization of InP semiconductors. J Colloid Interface Sci 2009;337(2): 358-63.

[60] Cui Y, Kim SN, Jones SE, Wissler LL, Naik RR, McAlpine MC. Chemical functionalization of graphene enabled by phage displayed peptides. Nano Lett 2010; 10(11): 4559-65.

[61] Sanghvi AB, Miller KP, Belcher AM, Schmidt CE. Biomaterials functionalization using a novel peptide that selectively binds to a conducting polymer. Nat Mater 2005; 4(6): 496-502.

[62] Bazylinski DA, Frankel RB, Heywood BR, et al. Controlled biomineralization of magnetite $\left(\mathrm{Fe}_{3} \mathrm{O}_{4}\right)$ and greigite $\left(\mathrm{Fe}_{3} \mathrm{~S}_{4}\right)$ in a magnetotactic bacterium. Appl. Environ. Microbiol. 1995;61(9): 3232-39.

[63] Yan L, Zhang S, Chen P, Liu H, Yin H, Li H. Magnetotactic bacteria, magnetosomes and their application. Microbiol Res 2012; 167(9): 507-19.

[64] Arakaki A, Yamagishi A, Fukuyo A, Tanaka M, Matsunaga T. Coordinated functions of Mms proteins define the surface structure of cubo-octahedral magnetite crystals in magnetotactic bacteria. Mol Microbiol 2014; 93(3): 554-67.

[65] Perry CC, Keeling-Tucker T. Biosilicification: the role of the organic matrix in structure control. J Biol Inorg Chem 2000; 5(5): 537-50.
[66] Perry CC. Silicification: The processes by which organisms capture and mineralize silica. Rev Mineral Geochem 2003; 54(1): 291-327.

[67] Patwardhan SV, Mukherjee N, Steinitz-Kannan M, Clarson SJ. Bioinspired synthesis of new silica structures. Chem Commun 2003; 10: 1122-23

[68] Poulsen N, Sumper M, Kröger N. Biosilica formation in diatoms: Characterization of native silaffin-2 and its role in silica morphogenesis. Proc Natl Acad Sci 2003; 100(21): 12075-80.

[69] Sumper M, Kroger N. Silica formation in diatoms: the function of long-chain polyamines and silaffins. J Mater Chem 2004; 14(14): 2059-65.

[70] Kröger N, Sandhage KH. From diatom biomolecules to bioinspired syntheses of silica- and titania-based materials. MRS Bull 2010; 35(02): 122-26.

[71] Cha JN, Shimizu K, Zhou Y, et al. Silicatein filaments and subunits from a marine sponge direct the polymerization of silica and silicones in vitro. Proc Natl Acad Sci 1999; 96(2): 361-65.

[72] Rai A, Perry CC. facile fabrication of uniform silica films with tunable physical properties using silicatein protein from sponges. Langmuir 2010; 26(6): 4152-9.

[73] Addadi L, Joester D, Nudelman F, Weiner S. Mollusk shell formation: a source of new concepts for understanding biomineralization processes. Chemistry 2006; 12(4): 980-7.

[74] Oren EE, Tamerler C, Sahin D, et al. A novel knowledge-based approach to design inorganic-binding peptides. Bioinformatics 2007;23(21): 2816-22

[75] Oren EE, Notman R, Kim IW, et al. Probing the molecular mechanisms of quartz-binding peptides. Langmuir 2010;26(13): 11003-9.

[76] Emami FS, Puddu V, Berry RJ, et al. Force field and a surface model database for silica to simulate interfacial properties in atomic resolution. Chem Mater 2014;26(8): 2647-58.

[77] Lee YJ, Lee Y, Oh D, Chen T, Ceder G, Belcher AM. Biologically activated noble metal alloys at the nanoscale: For lithium ion battery anodes. Nano Lett 2010; 10(7): 2433-40.

[78] Chen AY, Deng Z, Billings AN, et al. Synthesis and patterning of tunable multiscale materials with engineered cells. Nat Mater 2014;13(5): 515-23.

[79] Seker UOS, Sharma VK, Akhavan S, Demir HV. Engineered peptides for nanohybrid assemblies. Langmuir 2014; 30(8): 2137 43

[80] Naik RR, Stone MO, Carter DC. Method of isolating binding peptides from a combinatorial phage display library and peptides produced thereby. WO $078451 \mathrm{~A} 2,2003$.

[81] Slocik JM, Naik RR. Synthesis of hybrid inorganic nanoparticle structures using peptides. US Patent 7905943, 2011.

[82] Naik R, Stone M, Carter D. Peptide templates for nanoparticle synthesis obtained through PCR-driven phage display method. US Patent 0172282, 2006.

[83] Hur HG, Kim JO, Kim DH, Myung NS. Gold binding peptides and shape-and size-tunable synthesis of gold nanostructures. US Patent 0280220, 2010.

[84] Shiba K, Sano K. Peptides capable of binding to titanium, silver and silicone. WO $010031 \mathrm{~A} 1,2005$.

[85] Fahnestock SR, Fosser KA, Parthasarathy A, Wang H. Peptides that bind to silica-coated particles. US Patent 0158822, 2010

[86] Wada A, Ito Y, Kitajima T. Method of selecting polypeptide sequence, and metal oxide or silicon-containing compound binding peptide and use thereof. WO $111832 \mathrm{~A} 1,2013$.

[87] Grinstaff M, Kenan D, Walsh E, Middleton C. Interfacial biomaterials. US Patent 0185870, 2003.

[88] Fahnestock SR, Kostichka KN, Parthasarathy A, Wang H. Iron oxide-binding peptides. US Patent 0158837,2010

[89] [89] Hatanaka T, Ishida N. Rare earth material-binding peptide and use thereof. WO $111407 \mathrm{~A} 1,2015$.

[90] Kawamura H, Shiba K, Kashiwagi K, inventors. Peptide capable of binding to ceramic material. Japan patent WO 007723 A1, 2010.

[91] Rosi NL, Chen CL. Templates for controlling synthesis of nanoparticles into discrete assemblies. US Patent 0100969, 2009.

[92] Robert ESII, Filocamo SF. Controlling morphology of titanium oxide using designed peptides. US Patent 8834831, 2014. 
[93] Vreuls C, Weerdt CVD, Archembeau C, Renard A. Inorganicbinding peptides and quality control methods using them. WO 000493 A2, 2010

[94] Cho NH, Cheong TC, Seong SY, Min JH, Wu JH. Composite of a protein comprising zinc oxide-bonding peptides and zinc oxide nanoparticles, and use thereof. WO 055980 A2, 2011.

[95] Buseman-Williams J, Huang X, Wang H, Whiting G. Long lasting waterproof sunscreen comprising metal oxide and peptide conditioner. US Patent 0249682, 2005.

[96] Mascarenhas D. Metal-binding therapeutic peptides. WO 056511 A2, 2008.

[97] Stepanov VG, Liu Y, Fox GE, Jackson GW, McNichols RJ. Metalbinding peptides. US Patent 8916376, 2014.

[98] Krauland EM, Kottmann S, Barbero RJ, Belcher A. High affinity metal-oxide binding peptides with reversible binding. WO 079053 A2, 2009.

[99] Imamura T, Yano T, Nomoto T, Kozaki S, Honma T, Tsuchitani A. Magnetic substance-biosubstance complex structure, peptide fragment capable of linking to magnetic substance and gene therefor, and process for structure. WO 097416 A1, 2004.

[100] Belcher A. Molecular recognition of materials. US Patent 0148380, 2003.

[101] Belcher AM, Smalley RE, Ryan E, Lee SW. Biological control of nanoparticles. WO 026590 A2, 2003.

[102] Belcher AM, Lee SW. Nanoscaling ordering of hybrid materials using genetically engineered mesoscale virus. WO 029431 A2, 2003.

[103] Belcher AM, Reiss B, Mao C, Solis D. Peptide mediated synthesis of metallic and magnetic materials. WO 033488 A2, 2004.

[104] Belcher AM, Peele B, Nam KT. Multifunctional biomaterials as scaffolds for electronic, optical, magnetic, semiconducting, and biotechnological applications. WO 037856 A2, 2005.

[105] Belcher AM, Lee SW, Iverson BL, Lee SK. Fabricated biofilm storage device. WO 036992 A2, 2004.

[106] Belcher AM, Mao C, Solis DJ. Inorganic nanowires. WO 067683 A2, 2005.

[107] Yi H, Lee KY, JANG C, Chang J. Peptide binding to graphitic materials and phage including same. US Patent 0309126, 2014.

[108] Jagota A, Lustig SR, Wang S, Wang H. Carbon nanotube binding peptides. WO 102020 A2, 2003.

[109] McAlpine MC, Mannoor MS. Use and making of biosensors utilizing antimicrobial peptides for highly sensitive biological monitoring. US Patent 0156688, 2012.

[110] Ittel SD, Cunningham SD, Rouviere PE, Fahnestock SR, O'brien JP. Clay-binding peptides and methods of use. WO 117564 A2, 2007.

[111] Cunningham SD, Ittel SD, O'Brien JP, Rouviere PE. Peptides for binding calcium carbonates and methods of use. US Patent 7754680, 2010.

[112] Bertozzi CR, Song J, Lee SW. Hydroxyapatite-binding peptides for bone growth and inhibition. WO 062776 A2, 2006.

[113] Sarikaya M, Somerman M, Tammerler-Behar C, Fong H, Zhang H, Gungormus M. Reagents and methods for treating dental disease. WO 166626 A1, 2012.

[114] Sarikaya M, Tamerler-Behar C, Oren EE, Samudrala VV. Method and system for designing polypeptides and polypeptide-like polymers with specific chemical and physical characteristics. US Patent 0070200, 2010.

[115] Belcher AM, Schmidt CE, Miller KPH, Sanghvi A. Composition, method and use of bi-functional biomaterials. WO 035612 A2, 2004.

[116] Murray CJ, Tijerina P, Van GFJC, Janssen GG. Phenolic binding peptides. WO 033482 A2, 2004.

[117] Cunningham S, Lowe D, O'Brien J, Wang H, Wilkins A. Polyethylene binding peptides and methods of use. US Patent 0141628, 2007.

[118] Cunningham S, Lowe D, O'Brien J, Wang H, Wilkins A. PMMA binding peptides and methods of use. US Patent 0265431, 2007.

[119] Schneider E, Schurmann G, Wagner P, Wang H, Cohen GM. Peptides having affinity for poly (benzyl methacrylate-comethacrylic acid) potassium salt copolymers and methods of use. US Patent 0310495, 2010
[120] Eiden S, Eble A, Weiss M, et al. System comprising bacteriophages and particles that contain active substances. WO 018964 A2, 2009.

[121] Eiden S, Eble A, Budde B, Plug S, Krüger P. Bacteriophages and coating material for surfaces. WO 065573 A1, 2009.

[122] Janssen GG, Murray CJ, Winetzky DS. Skin or hair binding peptides. WO 048399 A2, 2004.

[123] O'Brien J, Wang H, Wu Y. Peptide-based body surface coloring reagents. US Patent 0222609, 2006.

[124] Fahnestock S, O'Brien J, Wang H. Peptide based conditioners. US Patent 0107614, 2005.

[125] Huang X, O'brien JP, Wang H, Wu Y. Peptide-based body surface reagents for personal care. WO 028503 A1, 2006.

[126] Anton DR, Daly S, Bianchini RJ, et al. Peptide-based systems for delivery of cosmetic agents. US Patent 0247590, 2010.

[127] Alsop AW, Cheng Q, Decarolis LJ, Fahnestock SR, Gruber TM, Rouviere PE. Recombinant peptide production using a crosslinkable solubility tag. WO 015163 A1, 2009.

[128] Cunningham S, Lowe D, O'Brien J, Wang H, Wilkins A. Nylon binding peptides and methods of use. US Patent 0141629, 2007.

[129] Janssen GG, Murray CJ, Estell DA, Tijerina P, Chen Y. Methods for selective targeting. WO 079479 A2, 2001.

[130] Nolan GP, Rozinov MN. Fluorescent dye binding peptides. US Patent 7332356, 2008.

[131] Vodnik M, Zager U, Strukelj B, Lunder M. Phage display: selecting straws instead of a needle from a haystack. Molecules 2011; 16(1).

[132] Matochko WL, Cory Li S, Tang SKY, Derda R. Prospective identification of parasitic sequences in phage display screens. Nucleic Acids Res 2013; 42(3): 1784-98.

[133] Umlauf BJ, McGuire MJ, Brown KC. Introduction of plasmid encoding for rare tRNAs reduces amplification bias in phage display biopanning. BioTechniques 2015; 58(2): 81-4.

[134] Emami FS, Puddu V, Berry RJ, et al. Prediction of specific biomolecule adsorption on silica surfaces as a function of $\mathrm{pH}$ and particle size. Chem Mater 2014;26(19): 5725-34.

[135] Liang M, Limo MJ, Sola-Rabada A, Roe MJ, Perry CC. New insights into the mechanism of $\mathrm{ZnO}$ formation from aqueous solutions of zinc acetate and zinc nitrate. Chem Mater 2014; 26(14): 4119-29.

[136] Sola-Rabada A, Liang M, Roe MJ, Perry CC. Peptide-directed crystal growth modification in the formation of ZnO. J Mater Chem B 2015; 3(18): 3777-88.

[137] Puddu V, Perry CC. Interactions at the silica-peptide interface: the influence of particle size and surface functionality. Langmuir 2014; 30(1): 227-33. 